\title{
- Case Report
}

\section{Pilomatrixoma of eyelid in a middle aged}

\author{
Passi N, Chawla U, Jyoti, Khurana AK \\ Regional Institute of Ophthalmolgy, Pt BD Sharma, Post Graduate Institute of Medical Sciences \\ (PGIMS), Rohtak, Haryana, INDIA
}

\begin{abstract}
Background : Pilomatrixoma, also known as Malherbes's calcifying epithelioma, known to occur in children, is not common especially in middle aged and those below 10 years of age . Pilomatrixoma presents as a firm skin nodule on eye lid or eye brow, so should be considered in the differential diagnosis of such lesions involving eyelids.
\end{abstract}

Case : A 45-year-old male presented with a swelling in the left upper lid for the last 4 months. There was firm to hard non tender nodule measuring $1.5 \mathrm{~cm}$. x $1.5 \mathrm{~cm}$ in size on the lateral aspect of the left upper eye lid, involving the lid margin with variegated appearance of overlying skin with a few ulcerated areas on the surface. A presumptive diagnosis of meibomian gland carcinoma was made and an excision biopsy with primary lid repair was carried out. Histopathological examination confirmed the diagnosis of pilomatrixoma.

Conclusion : The present case is reported to sensitize the ophthalmologists to think beyond chalazion and meibomian gland carcinoma for a firm, nodular, non ulcerated, painless lid swelling.

Key words : Pilomatrixoma, Malherbes's calcifying epithelioma, eyelid nodule

\section{Introduction}

Pilomatrixoma, also known as Malherbes's calcifying epithelioma, known to occur in children, is not common especially in middle aged and those below 10 years of age (Taffe et al 1988; Ahmad et al 1992; Wells et al 1994). Though not very rare, pilomatrixoma is usually not considered in differential diagnosis of a firm skin nodule on eye lid or eye brow. The present case is being reported to highlight that this entity should also be considered in the differential diagnosis of such lesions involving eyelids.

\section{Case report}

The present case reports a 45 years old male who presented with a swelling in the left upper lid for the

Received on: 13.05.2010 Accepted on: 12.12.2010

Correspondence and reprint request to:Dr Neebha Passi

Professor, Regional Institute of Ophthalmology,

PT. B. D. Sharma, PGIMS, Rohtak, Haryana (INDIA)

H.N.56/9J Medical Campus, Rohtak (haryana)

Email id : drneebha@yahoo.co.in

$\mathrm{Ph}$ no- 09215557072 last 4 months. On examination a firm to hard non tender nodule measuring $1.5 \mathrm{~cm} . x 1.5 \mathrm{~cm}$ in size was palpable on the lateral aspect of the left upper eye lid, involving the lid margin. (Figure-1). The overlying skin showed a variegated appearance with a few ulcerated areas on the surface. The nodule was firmly adherent to the underlying lid tissue. A presumptive diagnosis of meibomian gland carcinoma was made and an excision biopsy with primary lid repair was carried out. However, histopathological examination confirmed the diagnosis of pilomatrixoma showing a biphasic population composed of basaloid germinative cells and eosinophil shadow cells with a few foci of dystrophic calcification. (Figure-2)

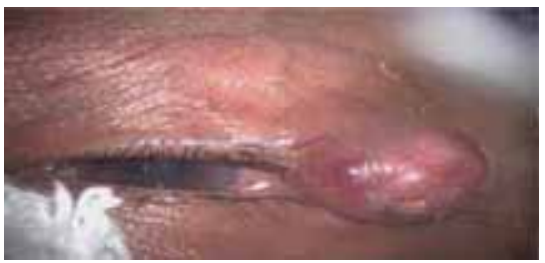

Fig 1: Pilomatrixoma involving lid margin 


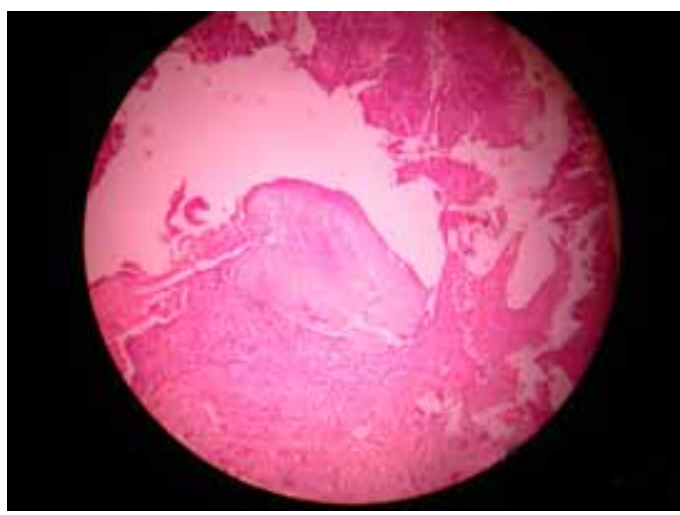

Figure.2- Histopathlogical picture of pilomatrixoma of lid

\section{Discussion}

Pilomatrixoma is an ectodermic tumour originating from pluripotential precursors of hair matrix cells. It can present at any age. It demonstrates a bimodal peak presentation during 1 st and 6th decades of life, about $40 \%$ of cases occur in patients younger than 10 years of age and $60 \%$ of cases occur within the first two decades of life (Taffe et al 1988; Ahmad et al 1992; Wells et al 1994). Multiple and familial pilomatrixomas are associated with Steinert's myotonic dystrophy, Gardner Syndrome, Turner Syndrome and Trisomy 9 (Aslan et al 1996; Berberian et al 1997; Naguchi et al 1999).These pilomatrixomas are much rarer than the solitary tumors. In the present case the solitary tumour was not associated with any systemic lesion.

Pilomatrixoma, though can involve any part of skin comprising of hair follicles, is comparatively more common in head and neck area and may occur at eye brow, eye lid and canthal area. It has been suggested that the distribution of pilomatrixoma matches the density of hair follicles in a given area.Approximately 50\% lesions occur on the head and neck area ( Shields et al 1995 ; Rotenberg et al 1996; Levy et al 2008) .

Preceding trauma, infection or bite at the site of occurrence of tumour has been reported, however, their significance in the pathogenesis of pilomatrixoma is not known. There was not history of any such predisposing factor in the present case. In general pilomatrixoma is not hereditary. The pathogenic mechanism of its development is associated to mutations in the betacatenine gene (CTNNB1) (Hassanein et al 2004) and it has been confirmed that this mutation does not only occur in pilomatrixoma but also in hair follicle carcinoma.

Pilomatrixoma typically presents as a solitary firm non tender subcutaneous nodule, adherent to skin but not fixed to underlying tissue. Growth is usually slow and may occur over a period of months to years. It is frequently mis-diagnosed as epidermoid cyst, sebaceous cyst, dermoid cyst, foreign body reaction, pyogenic granuloma and chalazion. Perforating or rapidly growing pilomatrixomas can mimic neoplastic lesions. Radiological imaging is of little diagnostic value for pilomatrixoma.

Histologically pilomatrixoma is characterized by a mass made up by basaloid cells in periphery, ghost cells in central part and calcification and sometimes ossification. The ghost cells represent necrotic areas of previously vital basaloid cells. The calcification and ossification areas appear progressively in necrosis areas. Ghost cells are pathognomic of pilomatrixoma.

Since this does not regress spontaneously, excision is the treatment of choice. Surgical excision including clear margins and its overlying skin prevent recurrence in most cases.

\section{Conclusion}

The present case is reported to sensitize the ophthalmologists to think beyond chalazion and meibomian gland carcinoma for a firm, nodular, non ulcerated, painless lid swelling.

\section{References}

Ahmad M, Khan IU, Khan AH, Rehman SB, Zubairi AM. Pilomatrixoma: a retrospective study. Int.J.Dermatol. Oct 1992; 31(10):703-5.

Aslan G, Erdogan B, Akoz T, Gorgu M, Seckin S, Terzioglu A. Multiple occurrence of pilomatrixoma. Plast Reconstr. Surg. Sept.1996;98(3):510-3.

Berberian BJ, Coloma TM, Battaglia M, ulica VI. Multiple pilomatrixomas in association with myotonic 
dystrophy \& a family history of melanoma. J Am Acad.Dermatol. Aug.1997; 37 (2 pt.1):268-9.

Hassanein AM,Glanz SM.Beta-catenin expression in bening and malignant pilomatrixxxx neoplasms. Br J Dermatol 2004; 150:511-516.

Levy J,Ilsar M, Deckel Y, Maly A, Anteby I, Pe'er J. Eyelid pilomatrixoma-A description of 16 cases and a review of the literature. Surv.Ophthalmol .Sept-Oct.2008; 53(5):526-35.

Naguchi H, Kayashima K, Nishiyama S, Ono T. Two cases of pilomatrixoma in Turner's Syndrome.Dermatology. 1999; 199 (4):338-40.

Rotenberg M, Laccourreye O, Cauchois R, Laccourreye L, Putterman M, Brasnu D. Head and neck pilomatrixoma. Am J otolaryngol. Mar-Apr 1996; 17 (2):133-5.

Shields JA, Shields CL, Eagle RC Jr, Mulvey L, Pilomatrixoma of eye lid. J Pediatr Ophthalmol Strabismus. Jul-Aug.1995; 32 (4):260-1.

Taaffe A,Wyatt EH, Bury HP.Pilomatrixoma (Malherbe):A clinical and histo pathologic survey of 78 cases. Int. J Dermatol. Sept.1988;27(7):477-80.

Wells NJ,Blair GK, Magee JF, Whiteman DM,Pilomatrisoma:a common benign childhood skin tumour. Can J Surg. Dec.1994;37(6):483-6.

\section{Source of support: nil. Conflict of interest: none}

